\title{
Manajemen Public Relation Dalam Meningkatkan Public Interest Pada Lembaga Pendidikan Islam
}

\author{
M. Ilyas Junaidi Addahil \\ Universitas Nurul Jadid \\ Ilyasjunaidi29@gmail.com
}

\begin{abstract}
Abstrak
Schools and communities are two inseparable environments. School is a place for learning, and society is a place where the output of learning can be implemented. The community is expected to support and participate in developing the educational process in schools. In this case, a strategy or management is needed to involve the community in educational activities in schools. The effort to make it real is to build good relations between school managers and the community so that they work together together and comprehensively. An educational institution should try to create a positive image in the heart of the community, so that the community is able to make a decision to register their sons and daughters and participate actively in the development of these educational institutions. To realize this positive image, in addition to developing quality it also requires productive community relations activities based on clear functions, roles, and visions. The purpose of this study is to assess and obtain a general description of the role of public relations and strategies at Islamic universities in imaging institutions and the image of the institution. This study uses a case study with a qualitative approach, while the theory is symbolic interaction and organizational information.This paper offers an alternative to implementing effective public relations roles and functions and how to apply public relations vision and mission in educational institutions.
\end{abstract}

Keyword: Urgency, Public Relations, Educational Institutions.

\section{PENDAHULUAN}

Hubungan masyarakat ialah sesuatu yang sengaja dilakukan, diplanningkan secara terus menerus untuk menciptakan saling mengerti antara lembaga dengan masyarakat. Public Relations (PR) adalah seni serta ilmu sosial dalam menganalisis tren, memprediksi konsekuensi, memberikan arahan kepada para pemimpin lembaga dan melaksanakan program yang diplaningkan yang dapat memenuhi kepentingan kedua lembaga dan masyarakat yang terkait ${ }^{1}$.

Public Relations (PR) adalah fungsi manajemen yang telah direncanakan agar mencapai tujuan tertentu yang sebelumnya harus memiliki proker yang jelas dan

${ }^{1}$ M. P. Morissan, Manajemen Publik Relation Strategi Menjadi Humas Profesional. (jakarta: perdana media group., 2008).hlm.24 terperinci, mencari fakta, merencanakan, berkomunikasi, dan mengevaluasi hasil dari apa yang telah mereka capai. Hubungan masyarakat masih merupakan bidang baru, terutama di negara Indonesia.Kelahiran humas seperti yang dipraktikkan saat ini adalah karena kemajuan di berbagai bidang $^{2}$. Perkembangan yang juga merupakan kekuatan tersendiri dalam masyarakat, memilah manusia menjadi beberapa kelompok atau komunitas, yang masing-masing memiliki tujuan tersendiri dan berusaha untuk mencapai target tersebut sebaik mungkin.

Ada faktor-faktor tertentuyang mempengaruhi sikap, perilaku dan produktivitas para pekerja.Temuan mereka

${ }^{2}$ Nasution, Manajemen Humas Di Lembaga Pendidikan., UMM Press (Malang: UMM Pers, 2006).hlm.58 
menunjukkan bahwa sikap dan perilaku positif serta produktivitas para karyawan tidak terlalu dipengaruhi oleh fasilitas dankondisi kerja, melainkan oleh perhatian manajemen pada mereka.Temuankedua ialah bahwa perilaku seorang pekerja sangat ditentukan dan terikatoleh norma-norma kelompok kerja dimana seseorang menjadi anggota. $^{3}$

Berdasarkan hal-hal ini, hubungan masyarakat merupakan suatu hal yang diharuskan dalam masyarakat saat ini, di mana msyarakat bergerak di berbagai bidang, misalnya di bidang industri, bisnis, pendidikan, ${ }^{4}$ pemerintah, sosial ekonomi, perburuan politik dll. Banyak orang tidak percaya dan merasa sulit untuk percaya bahwa hubungan masyarakat bermanfaat bagi organisasi atau lembaga mereka, dengan asumsi bahwa itu disebabkan oleh kesalahan dalam menerapkan hubungan masyarakat itu sendiri, penerapan hubungan masyarakat kadang-kadang lebih condong tidak menyatu dengan bagian-bagian lain , dan tidak terencana dengan baik. Sedangkan hubungan masyarakat tidak berbeda dengan fungsi manajemen lainnya, yang membutuhkan perencanaan, pengorganisasian, aksi dan evaluasi, dalam arti kerja humas haruslah terencana dengan baik, dan dirumuskan tujuannya serta ditentukan tingkat keberhasilannya ${ }^{5}$.

Pendekatan humas tidak harus
dilihat semata-mata sebagai alat kelembagaan, seperti dalam bentuk Bagian Hubungan Masyarakat atau Biro Hubungan Masyarakat. Hal utama adalah penerapannya sebagai cara komunikasi oleh

\footnotetext{
${ }^{3}$ Ahmad Fauzi, 'Pengembangan Human Relation Perspektif Nilai-Nilai Al- Qur ' An', Mutawatir, 1.2 (2011), 168-69.

4 Hefniy, 'Membangun Pendidikan Berbasis Islam Nusantara (Pendidikan Berbasis
}

setiap karyawan. Menimbang bahwa dibutuhkan waktu yang lama untuk membuat setiap karyawan dapat menerapkan hubungan masyarakat sebagai cara komunikasi dalam kehidupan dan kegiatan sehari-harinya, keberadaan hubungan masyarakat sebagai lembaga di dalam pemerintah kabupaten dan kota tentu masih diperlukan. Selain dua pendekatan itu, masih dimungkinkan pendekatan ketiga yakni peran humas dirangkap top manager atau perangkat pemerintah lain. Kemungkinan lainnya, pemerintah mempekerjakan konsultan jasa di bidang public relations yang berada di luar struktur pemerintahan, terus-menerus atau secara insidental.

Selain pendekatan yang telah disebutkan ada kemungkinan pendekatan ketiga yakni peran dan fungsi humas dirangkap sekaligus dengan top manager atau perangkat pejabat pemerintah lainnya. Kemungkinan lainnya, pemerintah memberikan pekerjaan sebagai konsultan jasa di bagian humas / public relations yang berada di luar struktur pemerintahan, secara insidental atau secara continue. Di era ini, hubungan masyarakat sebagai salah satu fungsi manajemen dalam pemerintahan kabupaten atau kota perlu dipertahankan bahkan perannya harus ditingkatkan. Meningkatkan perannya dengan memperbarui dan mengadaptasi konsep hubungan masyarakat yang telah kita ketahui sejauh ini, dan menerapkan konsep hubungan masyarakat dalam manajemen modern sejalan dengan tuntutan dan

Karakter Atau Akhlakul Karimah ?)', Jurnal ISlam, 1.1 (2017), 36-42.

${ }^{5}$ Machali..hlm.125 
tantangan zaman Reformasi, zaman Masyarakat Informasi dan Daerah otonomi

\section{Hakikat Manajemen}

Pemahaman tentang manajemen telah dibahas oleh banyak pakar, tetapi definisi manajemen itu sendiri tergantung pada sudut pandang dan keyakinan masingmasing definisi. Beberapa pakar mendefinisikan manajemen sebagai berikut:

Terry menyatakan bahwa: manajemen merupakan sebuah proses yang khas, yang terdiri dari tindakan-tindakan: planning, organizing, Actualiting, controling, dan evaluating yang dilakukan untuk menentukan serta mencapai sasaransasaran yang telah ditetapkan dengan memanfaatkan sumber daya manusia serta sumber-sumber lainnya6.

Menurut pendapat James F. Stoner, yang dikutip oleh Handoko menyatakan bahwa: Manajemen adalah proses Planning, Organizing, Actualiting, dan controling anggota dan sumber daya lainnya untuk mencapai tujuan organisasi yang telah ditetapkan7. Sementara Darmono menyatakan bahwa manajemen hanyalah sebuah proses mengoptimalkan kontribusi manusia, material, dan anggaran untuk mencapai tujuan organisasi.8 Berdasarkan pemahaman yang telah dijelaskan, kita dapat menarik benang merah bahwa manajemen pada dasarnya adalah seni atau proses dalam menyelesaikan sesuatu yang berkaitan dengan pencapaian tujuan ${ }^{9}$.

\footnotetext{
${ }^{6}$ George R Terry, Asas-Asas Menejemen. Terj. Winardi (Bandung: PT Alumni, 2006).hlm4

7 T Hani Handoko, Manajemen, BPFEYogyakarta, 2nd edn (Yogyakarta, 2008). hlm 8

${ }^{8}$ Darmono, Manajemen Dan Tata Kerja Perpustakaan Sekolah., Remaja Rosdakarya (Jakarta: PT Gramedia, 2001). hlm 14

9 Zamroni Hasan Baharun, Manajemen Mutu Pendidikan: Ikhtiar Dalam Meningkatkan Mutu Pendidikan Madrasah Melalui Pendekatan
}

\section{Hakikat Public Relation}

Istilah Public relation sering diartikan menjadi "Hubungan Masyarakat (Humas)."10 Pengertian humas adalah melaksanakan program yang terencana mengenai kegiatan-kegiatan yang melayani baik untuk kepentingan organisasi maupun kepentingan publik atau umum.

Menurut kesepakatan para ahli public relations atau hubungan masyarakat dalam kesepakatan the statement of mexico yang dikutip oleh Rosady Ruslan menyatakan bahwa praktik public relations adalah seni dan ilmu pengetahuan sosial yang dapat dipergunakan untuk menganalisis kecenderungan, memprediksi konsekwensi-konsekwensinya, menasihati para pemimpin organisasi, dan melaksanakan program yang terencana mengenai kegiatan-kegiatan yang melayani baik untuk kepentingan organisasi maupun kepentingan publik atau umum.11

Menurut Cristian yang dikutip oleh Soleh dan Elvinaro menyebutkan bahwa hubungan masyarakat atau public relations merupakan usaha yang secara sadar memotivasi agar orang-orang terpengaruh, terutama melalui komunikasi, agar timbul pikiran yang sehat terhadap suatu organisasi, memberi rasa hormat, mendukung dan bertahan dengan berbagai cobaan dan masalah.12

Balanced Scorecard (Tulungagung: Akademia Pustaka, 2017). Hlm. 5

10 Rahmat Kriyantono, Public relation Writing, (Jakarta: Kencana, 2012), hlm3.

11 Rosady Ruslan, Manajemen Public relation \& Media Komunikasi. (Jakarta: PT. Raja Grafindo Persada, 2003 ), hlm 17.

12 Soleh Sumatri dan Elvinaro Ardianto, Dasar-Dasar Public relation, (Bandung: Remaja Rosadakarya, 2006), hlm17. 
Sedangkan menurut Frank Jefkins, public relations adalah semua bentuk komunikasi yang terencana, baik itu kedalam maupun keluar, antara suatu organisasi dengan semua khalayaknya dalam rangka mencapai tujuan-tujuan spesifik yang berlandaskan pada saling pengertian.13

Menurut Ibnu Syamsi sebagaimana dikutip oleh Suryosubroto, hubungan masyarakat adalah kegiatan organisasi untuk menciptakan hubungan yang harmonis dengan masyarakat agar mereka mendukungnya dengan sadar dan sukarela.14

Menurut Oemi Abdurrachman sebagaimana dikutip oleh Sulistyorini, menyatakan bahwa hubungan masyarakat adalah menumbuhkan hubungan baik antara segenap komponen pada suatu lembaga dalam rangka memberikan pengertian, menumbuhkan motivasi dan partisipasi. Semua ini bertujuan untuk menumbuhkan dan mengembangkan pengertian dan kemauan baik (good will) publiknya serta memperoleh opini publik yang menguntungkan (untuk menciptakan kerjasama berdasarkan hubungan yang baik dengan publik). 15

Jadi hubungan masyarakat atau public relations merupakan semua bentuk komunikasi yang dilakukan secara sadar, sengaja dan terencana baik kedalam maupun keluar yang dilakukan, anatara organisasi dengan publiknya dalam rangka mencapai tujuan-tujuan yang spesifik yang berlandaskan pada saling pengrtian, sehingga akan memudahkan organisasi untuk meminta dukungan dalam

\footnotetext{
${ }^{13}$ Frank Jefkins.. Public relation (Jakarta: Gelora Aksar1998), hlm 10.

${ }^{14}$ Suryosubroto. Manajemen Pendidikan Di Sekolah (Jakarta: PT. Rineka Cipt 2004), hlm 155.
}

menjalankan setiap kegiatan dan programnya.

\section{Urgensi Humas di Lembaga Pendidikan}

Peranan Public Relations / Humas dalam organisasi / Lembaga menurut Cutlip dan kawan-kawan terdiri dari 4 (empat) peranan besar yang bisa saja dilaksanakan secara keseluruhan secara ber- gantian dalam satu organisasi, atau sebagian saja. Empat peranan tersebut masing-masing adalah,

\section{a. Teknisi Komunikasi (Communication} Technician);

Peranan Public Relations yang dimaksud ialah mengerjakan teknis operasional seperti menyunting dan menulis majalah, menulis siaran pers, karangan khas, artikel, membuat dan mengembangkan situs web, serta banyak memproduksi berbagai macam pesan yang akan dikomunikasikan. Untuk itu membutuhkan kecakapan dalam jurnalistik dan komunikasi,

b. Penentu Ahli (expert prescriber);

PR dalam menjalankan peranan sebagai penentu ahli adalah mendefinisikan masalah, membuat perencanaan program dan bertanggung jawab penuh atas pelaksanaan program komunikasi,

c. Fasilitator Komunikasi (communication facilitator);

Fungsi PR di sini adalah sebagai penghubung, penerjemah dan mediator antara organisasi dan publik. Pengelolaan komunikasi dilakukan secara dua arah. PR memfasilitasi perubahan-perubahan dengan

15 Sulistyorini.. Manajemen Pendidikan Islam, Konsep, Strategi dan Aplikasi (Yogyakarta: Teras, 2009), hlm 144 
menyingkirkan rintangan serta membuat saluran komunikasi terbuka dan menyediakan informasi yang diperlukan kedua pihak (organisasi dan publik), sehingga keduanya dapat membuat keputusan yang saling menguntungkan. Praktisi PR berfungsi sebagai nara sumber informasi dan kontak resmi antara organisasi dengan publiknya.

d. Fasilitator Penuntasan Masalah (Problem solver facilitator);

PR dalam keadaan itu bekerja sama dengan manajer lain untuk mengartikan dan menyelesaikan masalah. Mereka adalah bagian dari tim planning strategis. Pegiat hubungan masyarakat dalam hal ini membantu manajemen menyelesaikan persoalan dengan menerapkan proses manajemen untuk menganalisis masalah, membuat rencana dan mengimplementasikan dan mengevaluasi.. Keterlibatan manajer lini lainnya, secara psiko- logis akan meningkatkan sense of belonging terhadap permasalahan hubungan masyarakat dan diselesaikan secara strategis serta komit- men yang kuat di setiap lininya ${ }^{16}$

Masing-masing peranan Public Relations di atas, dapat diterapkan sesuai karakteristik organisasi atau pun kasuskasus yang terkait dengan publik yang dihadapi oleh organisasi. Apabila publik internal dan eksternal sangat luas dan beragam serta memiliki permasalahan yang sulit serta tidak dapat terdeteksi sebelumnya, maka dibutuhkan peranan expert prescriber atau penentu ahli. Organisasi memberikan kewenangan penuh kepada PR untuk menemukan permasalahan,

${ }^{16} \mathrm{C}$. d. Cutlip, Effective Public Relations. (Prentice Hall: New Jersey., 2000).hlm.62 menyelesaikan masalah dan bertanggungjawab penuh terhadap hal-hal tersebut. Sebaliknya makin rendah jumlah dan rintangan publik terhadap suatu organisasi, maka peranan PR cukuplah hanya sebagai communication technician yakni lebih kepada pe-laksanaan PR secara teknis.

Sementara Dr. Astrid S. Susanto dalam bukunya "Filsafat Komunikasi" menyatakan bahwa sebagai bagian fungsi manajemen yang berencana dan berkesinambungan, Humas tidak saja mempengaruhi khalayak agar mau mendukung kebijakan yang dijalankan, tetapijuga untuk menjernihkan pendapat yang tidak menguntungkan badan yang diwakilinya. Karena bagaimana pun di dalam menjalankan tugasnya, Humas memerlukan dukungan dari masyarakat ${ }^{17}$

\section{Fungsi public relation di lembaga pendidikan islam}

Berbicara fungsi berarti berbicara masalah kegunaan humas dalamtujuan organisasi/lembaga. Beberapa fungsi humas menurut pakar Humas berdasarkan ciri khas kegiatan humas ${ }^{18}$ sebagai berikut:

a. Menunjang aktivitas utama manajemen dalam mencapai tujuanbersama melalui fungsi melekat pada manajemenlembaga/organisasi.

b. Membina hubungan yang harmonis antara agensi / organisasi dan publik yang menjadi target audiens.

c. Identifikasi semua hal yang terkait dengan pendapat, persepsi, dan tanggapan orang terhadap badan organisasi yang mereka wakili atau sebaliknya.

${ }^{17}$ Susanto..hlm.135

${ }^{18}$ R. Ruslan,.hlm.173 
d. Sajikan keinginan publik dan berikan saran.

e. kepada pemimpin manajemen untuk target dan manfaat bersama.

f. Menciptakan komunikasi lawan arah atau timbal balik dan mengatur aliran informasi, publikasi, dan massage dari badan / organisasi ke publik atau sebaliknya untuk menghasilkan citra positif bagi kedua belah pihak.

$$
\text { Sedangkan menurut Zulkarnain }
$$

Nasution fungsi humaspada institusi pendidikan sebagai berikut:

a. Mampu menjadi mediator dalam menyampaikan komunikasi langsung (komunikasi tatap muka) dan tidak langsung (melalui media / pers) kepada pimpinan lembaga publik internal.

b. Mendukung kegiatan yang berkaitan erat dengan pencitraan lembaga pendidikan. Dalam hal ini, PR bertindak sebagaiapengelola informasi kepada publik internal dan eksternal, seperti: menyampaikan informasi kepada pers dan promosi.

c. Menciptakan citra positif lembaga pendidikan $^{19}$.

\section{Manajemen Public Relation Dalam Meningkatkan Public Interest Pada Lembaga Pendidikan Islam}

Ada beberapa bentuk inovasi yang bisa dilakukan oleh setiap madrasah guna untuk menjaga existensi suatu madrasah dan meningkatkan daya saing madrasah di daerahnya, salah satunya adalah:

\footnotetext{
${ }^{19}$ Nasution.hlm.153
}

20 Akmal Mundiri, 'Strategi Lembaga Pendidikan Islam Dalam Membangun Branding Image', Pedagogik, 3.2 (2016), 58-72.

\section{a. Brand Image Madrasah}

Brand image adalah gambaran yang dirasakan oleh pengguna layanan setelah menggunakan layanan tersebut. ${ }^{20}$ setelah melalui penyampaian visi dan misi madrasah serta strategi yang dilakukan oleh madrasah, penilaian tersebut tentu merupakan hal yang mutlak dimiliki oleh pengguna layanan pendidikan, yang di sini difokuskan pada orang tua siswa dan masyarakat sekitar.

Brand image adalah ilustrasi tentang madrasah dan citra sebagai sekolah yang unggul dan luar biasa, sehingga telah mampu mempengaruhi persepsi wali siswa dan masyarakat. Sutisna telah menjelaskan bahwa manfaat brand image adalah sebagai berikut:

1. Konsumen dengan citra yang positif terhadap suatu merek, lebih mungkin untuk melakukan pembelian,

2. Perusahaan dapat mengembangkan lini produk dengan memanfaatkan citra positif yang telah terbentuk terhadap merek produk lama, dan

3. Kebijakan family branding dan leverage branding dapat dilakukan jika citra produk yang telah ada positif. $^{21}$

b. Menciptakan Program Unggulan

Dalam usaha membangun brand image madrasah, tentu saja dimulai dengan upaya membangun citra madrasah itu sendiri. Melalui menciptakan program-program unggulan untuk membentuk daya saing dalam

${ }^{21}$ Sutisna, 'Perilaku Konsumen Dan Komunikasi Pemasaran' (Bandung: Remaja Rosda Karya, 2001),.hlm 83 
menghadapi persaingan di dunia pendidikan.

Selain program kurikuler yang dipatenkan oleh pemerintah, sebuah lembaga juga harus mempunyai program ekstrakurikuler seperti pramuka, marching band, futsal, sepak bola, seni bela diri, bulu tangkis,tarian, dll. Sekolah selalu memfasilitasi siswa-siswa unggul untuk ikut serta dalam berbagai kompetisi di tingkat sekolah, desa, kecamatan dan kabupaten. Dan juga membangun budaya sekolah yang kondusif sehingga membuat siswa nyaman dan tenang sehingga mereka bisa belajar. Sekolah juga menyediakan pembelajaran tambahan dalam bentuk qiroatul Qur'an (tajwid) yang dilakukan setiap hari ketika selesai sholat di kelas.

Ide-ide kreatif dalam memunculkan program-program superior di madrasah tidak harus hanya muncul begitu saja. Ini didasarkan pada analisis lingkungan terlebih dahulu. melihat peluang untuk membuat terobosan dalam memiliki perlengkapan marching band. Dan ternyata hasilnya cukup menggembirakan, karena setelah memiliki marching band, banyak anak yang tertarik untuk bersekolah di madrasah dan tentu saja ini juga disertai dengan mendapatkan juara di tingkat kabupaten.

Tidak hanya melalui kegiatan ekstrakurikuler, madrasah juga dapat mendorong dan memfasilitasi siswanya untuk unggul dalam bidang akademik dan non-akademik. Selain sebagai tempat untuk mempromosikan keunggulan dalam madrasah, tujuan lain dari upaya ini adalah untuk melatih mental anak-anak. Tentu saja ini adalah pengalaman yang akan selalu mengesankan anak-anak.

Karakteristik sekolah unggulan menurut Ekosusilo adalah sekolah yang memiliki indikator sebagai berikut: (1) prestasi akademik dan non-akademik di atas rata-rata sekolah di wilayah mereka; (2) fasilitas dan infrastruktur serta layanan yang lebih lengkap; (3) sistem pembelajaran yang lebih baik dan waktu belajar yang lebih lama; (4) membuat seleksi pelamar yang cukup ketat; (5) mendapatkan banyak minat dari masyarakat, yang dibuktikan dengan banyaknya pendaftar dibandingkan dengan kapasitas kelas; (6) biaya sekolah lebih tinggi dari sekolah di sekitarnya

\section{PENUTUP}

Kesimpulan Dari penjelasan di atas dapat disimpulkan bahwa fungsi humas dialembaga pendidikan adalah menumbuhkan dan mengembangkan hubungan yang harmonis melalui komunikasi menggunakan media antara sekolah dan masyarakat, baik internal (dosen / guru, karyawan, siswa / siswi) dan secara eksternal (orang tua siswa , masyarakat, lembaga, dalam rangka mempublikasikan kegiatan hubungan masyarakat di lembaga pendidikan sehingga dapat menciptakan opini, citra, dan reputasi yang positif untuk lembaga pendidikan ini dan fungsi hubungan masyarakat di bidang pendidikan masa depan institusi dituntut untuk selalu profesional dalam mengelola informasi sehingga citra positif institusi terwujud dan akan sangat berdampak pada daya saing di kancah nasional, dengan demikian maka suatu lembaga akan tetap exis dalam menyelenggarakan pendidikan sehingga tujuan pendidikan diindonesia bisa dicapai dengan maximal.

\section{DAFTAR PUSTAKA}

Cutlip, C. d., Effective Public Relations. (Prentice Hall: New Jersey., 2000)

Dakir., Dakir. Perencanaan Dan Pengembangan Kurikulum ., Ilmiah Media Engineeeing (Prentice Hall: Jakarta: Rineka Cipta., 2014) 
Darmono, Manajemen Dan Tata Kerja Perpustakaan Sekolah., Remaja Rosdakarya (Jakarta: PT Gramedia, 2001)

Djunaidi, Iwan, Pelaksanaan KTSP Pada MTs Di Kalimantan Dan Jawa Timur, Balai Penelitian Dan Pengembangan Agama (semarang, 2010)

Fauzi, Ahmad, 'Pengembangan Human Relation Perspektif Nilai-Nilai alQur'an, Mutawatir, 1 (2011), 16869

Hani Handoko, T, Manajemen, BPFEYogyakarta, 2nd edn (Yogyakarta, 2008)

Hasan Baharun, Zamroni, Manajemen Mutu Pendidikan: Ikhtiar Dalam Meningkatkan Mutu Pendidikan Madrasah Melalui Pendekatan Balanced Scorecard (Tulungagung: Akademia Pustaka, 2017)

Hefniy, 'Membangun Pendidikan Berbasis Islam Nusantara (Pendidikan Berbasis Karakter atau Akhlakul Karimah ?)', Jurnal ISlam, 1 (2017), 36-42

Machali, I. d., Education Management: Teori Dan Praktik PengelolaanSekolah/Madrasah di Indonesia. (Jakarta: Kencana., 2016)
Muhaimin., Pengembangan Kurikulum Pendidikan Agama Islam. (jakarta: jakarta : PT Raja Grafindo Persada., 2012)

Mundiri, Akmal, 'Strategi Lembaga Pendidikan Islam Dalam Membangun Branding Image, Pedagogik, 3 (2016), 58-72

Mustofa, A., 'Perkembangan Kurikulum Pendidikan Agama Islam di Pesantren, Madrasah Dan Sekolah.', UMM Press, 2012

Oemar, H., Dasar-Dasar Pengembangan Kurikulum., ed. by Bandung: Remaja Rosdakarya., Rajawali (Jakarta: Rajawali, 2007)

Sukmadinata, Nana Saodih, Pengembangan Kurikulum Teori \& Praktek, Remaja Rosdakarya (Bandung: Remaja Rosdakarya, 1997)

Susanto, Ahamad, Filsafat Komunikasi. (Jakarta: Erlangga, 1994)

Sutisna, 'Perilaku Konsumen Dan Komunikasi Pemasaran' (Bandung: Remaja Rosda Karya, 2001), p. 83

Terry, George R, Asas-Asas Menejemen. Terj. Winardi ( 4, Pendidikan (Bandung: PT Alumni, 2006)

Wahid, Abdul, Isu Isu Kontenporer Pendidikan Islam (semarang: Refika Aditarma, 2009) 